УДК 004.8

DOI https://doi.org/10.32851/tnv-tech.2021.6.7

\title{
УДОСКОНАЛЕНИЙ АЛГОРИТМ ПРОВЕДЕННЯ ІНТЕРАКТИВНИХ ПРЕЗЕНТАЦІЙ ЗІ ЗВОРОТНОЮ КОМУНІКАЦІЄЮ
}

\author{
Савчук T.O. - PhD, \\ профресор кафедри комп'ютерних наук \\ Вінницького національного технічного університету \\ ORCID ID: 0000-0002-0061-6206 \\ Руденко М.В. - студент кафедри комп'ютерних наук \\ Вінницького національного технічного університету \\ ORCID ID: 0000-0003-2130-2385
}

Натепер інформація є найбільш иінним ресурсом у сучасному світі, є безліч способів донесення інформації до кінцевого користувача. Одним із таких способів є проведення презентацій. Зазвичай презентація - че набір слайдів, наповнених певною інформачією. Презентачії проводяться перед певною аудиторією із залученням спікера, який своєю чергою доносить інформачію зі слайдів.

Презентаиії проводяться у самих різних випадках і ситуаціях, від шкільних предметів до професійних зустрічей. Якість інформачії, що буде донесена чи засвоєна слухачами, напряму залежить від виступу доповідача, але також досить важливим фактором є сам процес подання інформації. Основною проблемою будь-якої презентації є сухість та одноманітність презентації. Зазвичай доповідач створює наповнені текстом слайди та «читає» інформацію з них. Саме тому прочес донесення інформачії до користувачів потребує удосконалення, ще своєю чергою визначає актуальність кваліфікачійної роботи. Одним з важливих етапів проведення інтерактивних презентацій є взаємодія з аудиторією, саме завдяки иьому забезпечується зв'язок доповідача та аудиторії. Зазвичай взаємодія забезпечується шляхом створення запитань до аудиторії. Це може бути опитування чи будь-яка інформачія, яку потрібно донести до слухачів.

Запропоновано удосконалений алгоритм проведення інтерактивних презентаиій за рахунок можливості вибору режиму ідентифікаиї̈ слухача презентації та використання інтерактивного опитування для покращення якості проведення презентацій. Запропонований функиіонал допоможе збільшити кількість запитань від слухачів до оратора за рахунок анонімного режиму ідентифікації, а також допоможе доповідачам налагодити зворотний зв'язок з аудиторією за рахунок інтерактивного опитування, що загалом збільшить якість проведення виступів та презентаиій.

Ключові слова: презентачія, вебдодаток, інтерактивна презентачія, взаємодія, доповidb.

Savchuk T.O., Rudenko M.V. Improved algorithm for interactive representations with feedback

Today, information is the most valuable resource in the modern world, there are many ways to convey information to the user. One such way is to give presentations. Usually, a presentation is a set of slides filled with certain information. Presentations are held in front of a certain audience with the involvement of a speaker, who in turn conveys information from the slides.

Presentations are held in a variety of cases and situations, from school subjects to professional meetings. The quality of the information that will be conveyed or assimilated by the listeners directly depends on the speech of the speaker, but also a very important factor is the process of presenting the information. The main problem of any presentation is the dryness and uniformity of the presentation. Usually, the speaker creates slides filled with text and "reads" information from them. That is why the process of conveying information to users needs to be improved, which in turn determines the relevance of qualification work. One of the important stages of interactive presentations is the interaction with the audience, which is why the speaker and the audience are connected. Interaction is usually provided by asking questions to the audience. This can be a survey or any information that needs to be communicated to the audience.

An improved algorithm for conducting interactive presentations is proposed due to the possibility of choosing the mode of identification of the listener of the presentation and the use 
of an interactive survey to improve the quality of presentations. The proposed functionality will help increase the number of questions from the audience to the speaker due to the anonymous identification mode, as well as help the speakers to establish feedback with the audience through an interactive survey, which will generally improve the quality of speeches and presentations.

Key words: presentation, web application, interactive presentation, interaction, report.

Аналіз підходів до проведення презентацій. У наш час презентації є досить потужним інструментом, що може використовуватись як для навчання або донесення корисної інформації, так і для реклами. Саме тому важливо підвищити якість проведення презентацій для засвоєння матеріалу чи донесення потрібної інформації більш якісно.

Презентації проводяться як перед «живою» аудиторією на сценах чи в залах, так і в мережах за допомогою сучасних засобів комунікації. Аудиторія на таких заходах може бути досить різноманітною - від школярів, які засвоюють матеріал зі шкільної програми, до спеціалістів у різних галузях, які діляться досвідом з колегами [1]. Досить часто проводяться умовні презентації у старому стилі, які є монологами доповідача. Саме тому досить важливо підібрати підхід до кожного слухача, адже кожен може втратити інтерес до презентації незабаром після її запуску [2]. Це, як правило, презентації, в яких відсутня «взаємодія», коли оратор весь час грає провідну роль і не дає можливості аудиторії реально брати участь у них [3].

Більшість презентацій використовують звичайний підхід до їх проведення за допомогою слайдів та тексту. Паралельно із презентацією оратор зачитує текст зі слайдів. Цей підхід не включає ніякої взаємодії зі слухачами, що може привести до втрати зацікавленості та уваги. Також він не забезпечує ніякої рівності між оратором та слухачами та не дає можливість відкритого зворотного зв'язку. Всі ці недоліки роблять підхід застарілим та неякісним. До переваг можна віднести простоту такого підходу як у реалізації, так і у використанні [4].

Одним із відомих підходів до проведення презентацій є надання можливості керувати вмістом презентації слухачам. Підхід дозволяє слухачеві самостійно вибирати інформацію, що транслюється на екрані, а слухачі можуть більше сконцентруватись на важливій для них інформації та повернутись до неї в будь-який момент. Цей підхід також допоможе знизити кількість запитань, які вже розглядались у рамках презентації, що позитивно вплине на увагу та зацікавленість аудиторії. Такий підхід активно використовується для проведення онлайн-презентацій. Однак цей підхід не забезпечує ніякого покращення у взаємодії між оратором та аудиторією, що є одним з актуальних завдань інтерактивних презентацій [5].

Одним із перспективних підходів $є$ проведення інтерактивних презентацій. Опитування аудиторії може відбуватись для динамічного отримання статистичних даних, які потрібні оратору для проведення презентації, або для перевірки якості засвоєння матеріалу, що досить важливо для навчальних заходів. Підхід забезпечує ефективну взаємодію та двосторонній зв'язок між оратором та аудиторією, а також забезпечує рівність позицій оратора з аудиторією, що важливо для зацікавлення та утримання уваги слухачів [6].

На основі аналізу підходів до проведення презентацій можна виділити такі основні характеристики якості підходів до проведення презентацій, як:

- донесення інформації;

- рівність позицій;

- відкритий зворотний зв'язок;

- отримання статистичних даних;

- простота; 
- залученість аудиторії;

- взаємодія.

Результати аналізу підходів до проведення презентацій за основними характеристиками зображено у таблиці 1.

Аналіз підходів до проведення презентацій

Таблиця 1

за основними характеристиками

\begin{tabular}{|l|c|c|c|}
\hline & $\begin{array}{c}\text { Виступ за } \\
\text { допомогою } \\
\text { слайдів }\end{array}$ & $\begin{array}{c}\text { Керування } \\
\text { вмістом }\end{array}$ & $\begin{array}{c}\text { Інтерактивна } \\
\text { презентація }\end{array}$ \\
\hline Донесення інформації & $\mathrm{Tа \kappa}$ & Так & Так \\
\hline Рівність позицій & $\mathrm{Hi}$ & Так & Так \\
\hline Зворотний зв'язок & $\mathrm{Hi}$ & $\mathrm{Hi}$ & $\mathrm{Hi}$ \\
\hline Статистичні дані & $\mathrm{Hi}$ & $\mathrm{Hi}$ & Так \\
\hline Простота & $\mathrm{Ta \kappa}$ & $\mathrm{Ta \kappa}$ & $\mathrm{Hi}$ \\
\hline Взаємодія з аудиторією & $\mathrm{Hi}$ & $\mathrm{Hi}$ & Так \\
\hline Залученість аудиторії & $\mathrm{Hi}$ & $\mathrm{Hi}$ & $\mathrm{Hi}$ \\
\hline
\end{tabular}

Як видно з таблиці 1, інтерактивна презентація має високу якість проведення презентацій серед інших у частині рівності позицій та взаємодії з аудиторією. Серед недоліків підходу слід відзначити відсутність зворотного зв'язку та складність у реалізації та використанні, а також недостатню залученість аудиторії.

Таким чином, метою дослідження можна визначити підвищення якості проведення інтерактивних презентацій за рахунок покращення зворотного зв'язку та залученості аудиторії в процесі презентації матеріалів.

Запропоноване рішення. Класичний алгоритм проведення презентації включає такі основні кроки [7]:

1. Запуск презентації.

2. Відображення слайду.

3. Перемикання слайду до тих пір, доки не буде відображений останній слайд.

4. Вимкнення презентації.

Проведення інтерактивних презентацій передбачає організацію взаємодії доповідача з його аудиторією. Процес взаємодії має відбуватись після відображення слайду і лише в тому разі, якщо цей слайд передбачає взаємодію, якщо ж ні, то після виступу слайд перемикається.

Тому алгоритм проведення інтерактивної презентації включає такі кроки, як:

1. Завантаження презентації.

2. Запуск режиму презентації.

3. Відображення слайду.

4. Виступ оратора по такому слайду.

5. Якщо слайд передбачає взаємодію, то відбувається взаємодія між оратором та аудиторією.

6. Перемикання слайду.

7. Якщо був презентований не останній слайд, то перейдемо до пункту 3. Інакше - до пункту 8.

8. Вимкнення презентації. 
UML-діаграма активності проведення інтерактивної презентації зображена на рисунку 1.

Одним 3 важливих етапів проведення інтерактивних презентацій є взаємодія 3 аудиторією, саме завдяки цьому забезпечується зв'язок доповідача та аудитоpiï. Зазвичай взаємодія забезпечується шляхом створення запитань до аудиторії. Це може бути опитування чи будь-яка інформація, яку потрібно донести до слухачів. Через відсутність зворотного зв'язку інтерактивні презентації не можуть бути досить ефективними, позаяк доповідач ніяк не може отримати запитання чи думку кожного зі слухачів.

Тому 3 метою покращення якості проведення презентацій доцільно додати до процесу проведення інтерактивних презентацій можливість створювати слайди зі зворотною комунікацією, тобто слайди, які дадуть можливість слухачам залишити відгук, поставити запитання чи уточнити інформацію, що стосується до презентації. Додати таку можливість пропонується на тому ж рівні із типовою взаємодією доповідача та аудиторії. Для цього потрібно перевіряти тип взаємодії, яка передбачена кожним слайдом [9].

Залученість аудиторії можна покращити за рахунок надання можливості слухачам взаємодіяти із презентацією, не ідентифікуючи себе. Додавання можливості кожному слухачеві вибирати режим ідентифікації (анонімно чи публічно) під час взаємодії із доповідачем.

У разі анонімного режиму ідентифікації доповідач та інші слухачі не будуть знати автора запитання чи відгуку, а у разі публічного, навпаки, кожен буде бачити ім'я автора. Такий функціонал покращить залученість аудиторії, а саме дасть можливість кожному слухачеві визначати ступінь анонімності та створить відчуття безпеки у процесі формування відгуків та запитань до лектора [10].

Удосконалений алгоритм проведення інтерактивних презентацій включатиме такі кроки:

1. Відображення слайду презентації, який передбачає будь-яку взаємодію, на екрані.

2. Якщо тип взаємодії, що передбачає такий слайд, - це питання доповідача до аудиторії, то перейти до пункту 9.

3. Відображення на екрані питання доповідача до аудиторії, що було поставлене під час створення презентації.

4. Відповідь на питання кожним слухачем за допомогою власного девайсу (смартфона, планшета, ноутбука).

5. Обробка кожної відповіді та виведення на слайд результатів у вигляді, що вибирався під час створення презентації.

6. Збереження всіх результатів опитування такого слайду для подальшого використання доповідачем.

7. Кінець алгоритму.

8. Надання можливості вибрати режим ідентифікації кожному слухачу за допомогою девайсу (публічний або анонімний).

9. Надання можливості створити питання, що цікавить кожного зі слухачів, або надати відгук до доповіді оратора за допомогою девайсу.

10. Запис усіх запитань у список.

11. Якщо автором був вибраний публічний режим ідентифікації, то на слайді відображується ім'я та прізвище автора питання. Якщо ж автор вибрав анонімний режим ідентифікації, то ім'я не відображається на слайді.

12. Відображення на слайді запитання до доповідача чи відгук, що були відправлені кожним слухачем. 


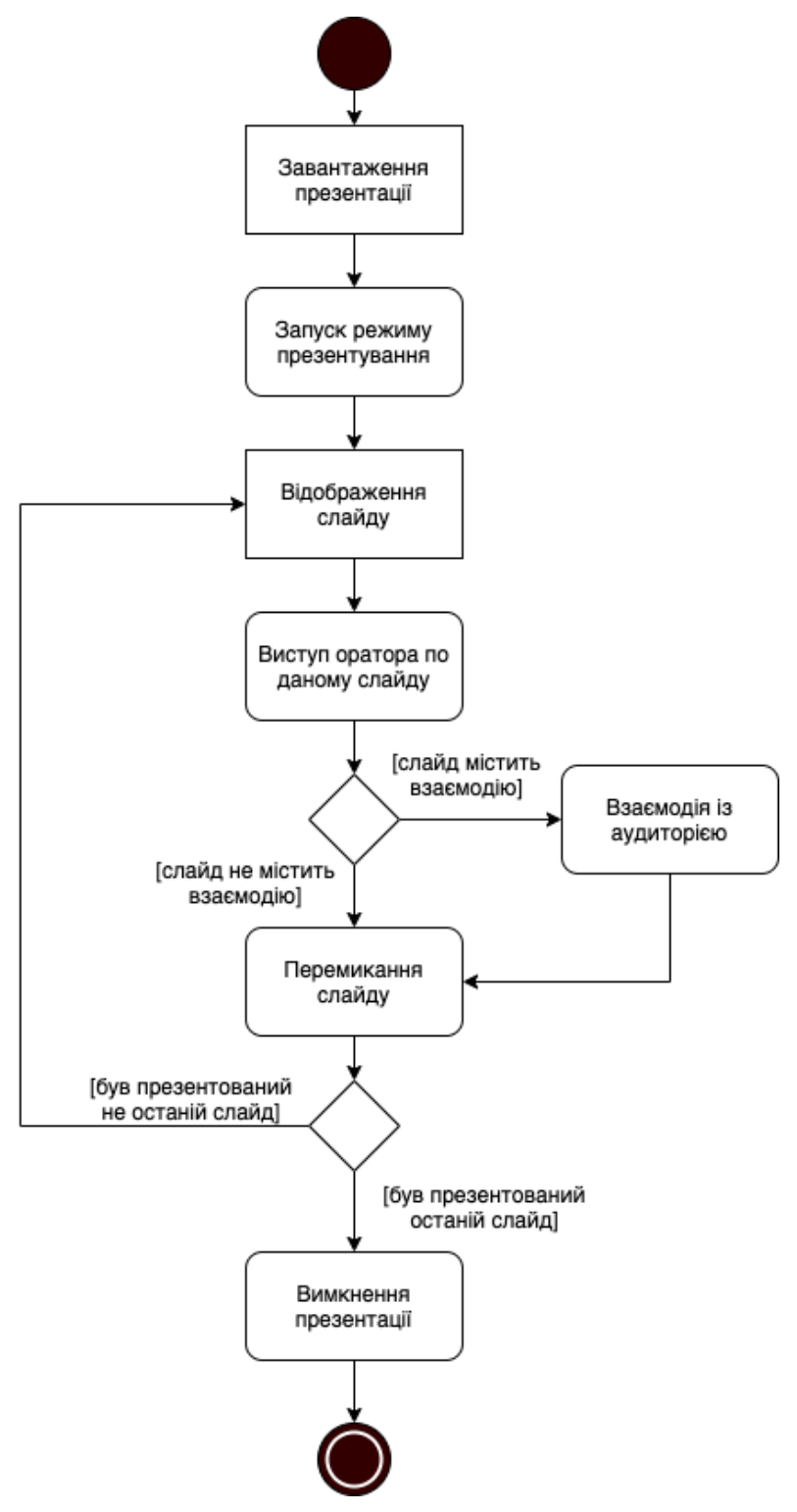

Pис. 1. UML-діаграма активності алгоритму проведення інтерактивної презентації

13. Отримання відповіді від оратора на таке запитання.

14. Видалення запитання зі списку.

15. Якщо у списку ще є запитання, то перейдемо до пункту 12.

16. Перейти до кроку 8.

UML-діаграма активності алгоритму зворотної комунікації між доповідачем та аудиторією представлена на рисунку 2.

Очікуваним ефектом процесу проведення презентацій можна вважати донесення або засвоєння інформації або матеріалу, рівність позицій, зворотний зв' язок, 


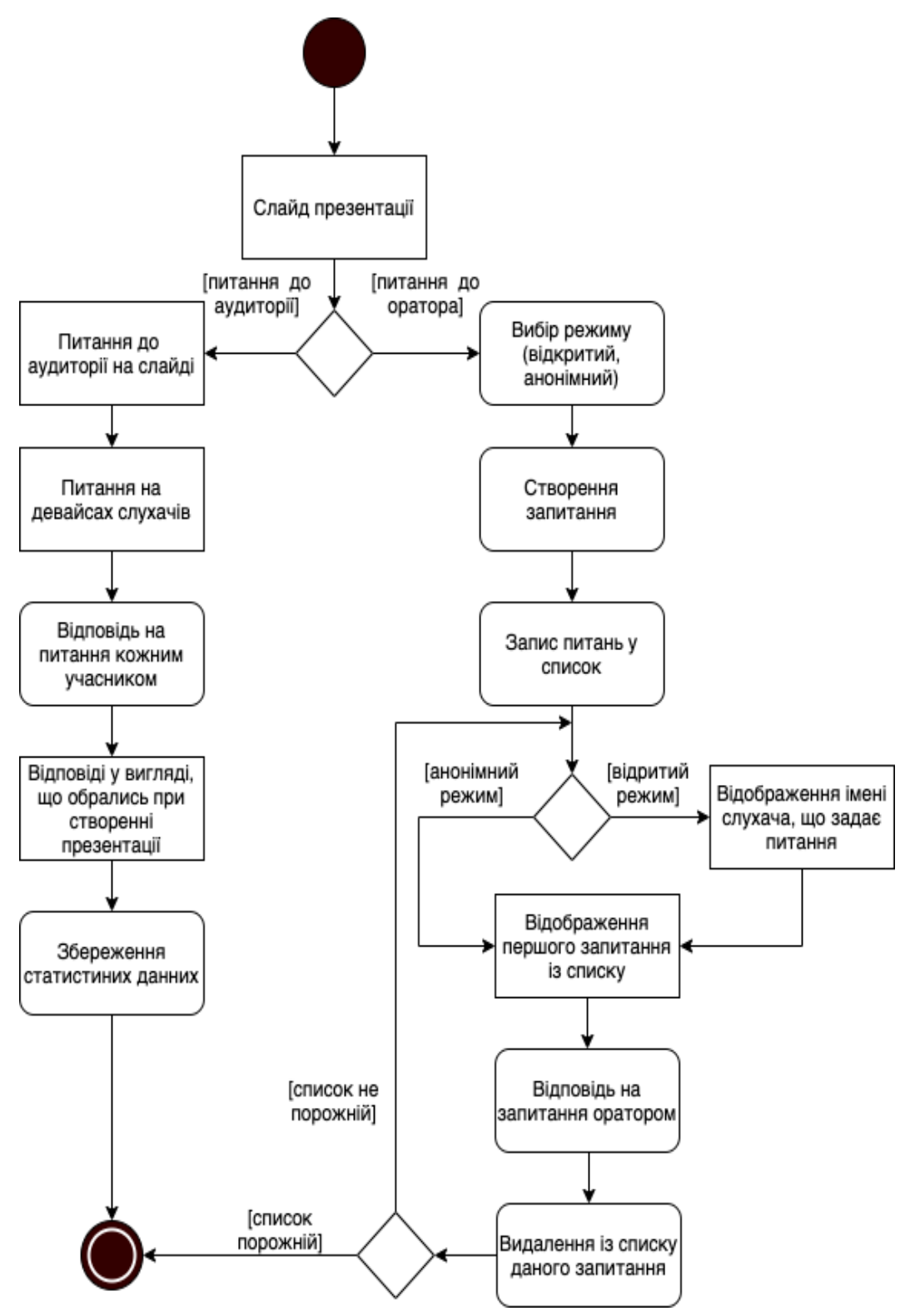

Puc. 2. UML-діаграма активності процесу удосконаленої зворотної комунікації між доповідачем та аудиторією

збереження статистичних даних, простоту використання, взаємодію з аудиторією та залученість слухачів.

3 метою дослідження якості запропонованого удосконаленого алгоритму проведення інтерактивних презентацій було проведено два типи презентацій:

1) за класичним алгоритмом презентації із різною кількістю слайдів, після чого всіх слухачів було опитано відповідно до матеріалу презентацій і визначено середній відсоток засвоєного матеріалу; 
2) за удосконаленим алгоритмом презентації із різною кількістю слайдів, після чого всіх слухачів було опитано відповідно до матеріалу презентацій і визначено середній відсоток засвоєного матеріалу.

Результати аналізу класичного та удосконаленого алгоритмів для проведення інтерактивних презентацій за основними характеристиками зображено у таблиці 2.

Таблиця 2

\section{Аналіз класичного та удосконаленого алгоритмів за основними характеристиками}

\begin{tabular}{|l|c|c|}
\hline \multicolumn{1}{|c|}{ Характеристика } & Клас. алгоритм & Удоск. алгоритм \\
\hline Донесення інформації & Так & Так \\
\hline Рівність позицій & Так & Так \\
\hline Зворотний зв'язок & Нi & Так \\
\hline Статистичні дані & Так & Так \\
\hline Простота & Нi & Ні \\
\hline Взаємодія з аудиторією & Так & Так \\
\hline Залученість аудиторії & Нi & Так \\
\hline
\end{tabular}

Результати проведених досліджень щодо покращення якості проведення інтерактивних презентацій за допомогою зворотного зв'язку та режиму ідентифікації наведені у таблиці 3.

Таблиця 3

Порівняльна характеристика якості класичного та удосконаленого алгоритмів проведення інтерактивних презентацій

\begin{tabular}{|c|c|c|}
\hline К-ть слайдів & Якість, \% (клас. алгоритм) & Якість, \% (удоск. алгоритм) \\
\hline 3 & 78 & 80 \\
\hline 6 & 64 & 78 \\
\hline 10 & 53 & 74 \\
\hline 15 & 48 & 71 \\
\hline 20 & 42 & 68 \\
\hline
\end{tabular}

Як видно з таблиць 2 та 3, якість проведення презентації, що визначається донесенням інформації, рівністю позицій, зворотним зв' язком, збереженням статистичних даних, простотою використання, взаємодією з аудиторією та залученістю слухачів, залежить від кількості слайдів. За мінімальної кількості слайдів якість проведення презентації за допомогою удосконаленого алгоритму на 1-2\% більша, якщо ж слайдів більше - якість більша на близько 20\%, що свідчить про підвищення якості проведення презентації.

Висновки. Таким чином, запропоновано удосконалений алгоритм проведення інтерактивних презентацій зі зворотною комунікацією, що базується на використанні зворотного зв'язку та режиму ідентифікації. За допомогою удосконалення було покращено такі характеристики, як:

- вибір режиму ідентифікації слухача презентації;

- використання зворотної комунікації з метою забезпечення онлайн-взаємодії між слухачами та оратором.

За рахунок зворотної комунікації аудиторія може донести свою думку чи поставити запитання доповідачу, а за допомогою вибору режиму ідентифікації 
кожен слухач може визначати ступінь анонімності та відчути безпеку у процесі формування відгуків та запитань до лектора.

Отже, запропоновано удосконалений алгоритм проведення інтерактивних презентацій за рахунок можливості вибору режиму ідентифікації слухача презентації та використання інтерактивного опитування для покращення якості проведення презентацій. Запропонований функціонал збільшить кількість запитань від слухачів до оратора за рахунок анонімного режиму ідентифікації, а також допоможе доповідачам налагодити зворотний зв'язок з аудиторією за рахунок інтерактивного опитування, що загалом збільшить якість проведення виступів та презентацій.

\section{СПИСОК ВИКОРИСТАНОЇ ЛІТЕРАТУРИ:}

1. Інтерактивне опитування, інтерв'ювання. URL: https://stud.com.ua/33971/ menedzhment/interaktivne opituvannya intervyuvannya.

2. Савчук Т.О., Руденко М.В. Розробка вебсервісу для проведення інтерактивних презентацій. 2020. URL: https://conferences.vntu.edu.ua/index.php/all-fitki/allfitki-2020/paper/view/9373.

3. Савчук T.О., Руденко М.В. Розробка для проведення інтерактивного опитування на конференціях і презентаціях. 2020. URL: https://conferences.vntu.edu.ua/ index.php/all-fitki/all-fitki-2020/paper/view/8922/7719.

4. Інтерактивна презентація. URL: https://studopedia.su/3_37736_Interaktivnaprezentatsiya.html.

5. Види і типи презентацій. URL: https://studfile.net/preview/5117935/.

6. How to make a good presentation. URL: https://biteable.com/blog/tips/how-tomake-good-presentation/.

7. How to Turn Survey Results Into Awesome Presentations. URL: https://www. getfeedback.com/resources/online-surveys/turn-survey-results-into-awesomepresentations/.

8. What is an interactive presentation? URL: https://3dforscience.com/what-is-aninteractive-presentation/.

9. Interactive Presentation Ideas. URL: https://www.powtoon.com/blog/interactivepresentation-ideas/.

10. Interactive Presentations Guidelines. URL: http://www.iafastro.org/wp-content/ uploads/2015/12/IAC-2016-Interactive-Presentations-Guidelines.pdf.

\section{REFERENCES:}

1. The interactive survey, interviews. Retrieved from: https://stud.com.ua/33971/ menedzhment/interaktivne opituvannya intervyuvannya

2. Savchuk, T.O., Rudeñko, M.V. (2020). Development of a web service for interactive presentations. Retrieved from: https://conferences.vntu.edu.ua/index.php/all-fitki/ all-fitki-2020/paper/view/9373.

3. Savchuk, T.O., Rudenko. M.V. (2020). Development for an interactive survey at conferences and presentations. Retrieved from: https://conferences.vntu.edu.ua/index. php/all-fitki/all-fitki-2020/paper/view/8922/7719.

4. Interactive presentation. Retrieved from: https://studopedia.su/3_37736_Interaktivna-prezentatsiya.html.

5. Types of presentations. Retrieved from: https://studfile.net/preview/5117935/.

6. How to make a good presentation. Retrieved from: https://biteable.com/blog/tips/ how-to-make-good-presentation/.

7. How to Turn Survey Results Into Awesome Presentations. Retrieved from: https://www.getfeedback.com/resources/online-surveys/turn-survey-results-into-awesome-presentations/.

8. What is an interactive presentation? Retrieved from: https://3dforscience.com/ what-is-an-interactive-presentation/.

9. Interactive Presentation Ideas. Retrieved from: https://www.powtoon.com/blog/ interactive-presentation-ideas/.

10. Interactive Presentations Guidelines. Retrieved from: http://www.iafastro.org/ wp-content/uploads/2015/12/IAC-2016-Interactive-Presentations-Guidelines.pdf. 